\title{
STAN WYJĄTKOWY I REŻIM SYTUACJI NADZWYCZAJNYCH W FEDERACJI ROSYJSKIEJ - KONTEKST OCHRONY ŚRODOWISKA
}

\section{THE STATE OF EMERGENCY AND THE REGIME OF EXTRAORDINARY SITUATIONS IN THE RUSSIAN FEDERATION - IN THE CONTEXT OF NATURAL ENVIRONMENT PROTECTION}

\section{STRESZCZENIE}

Położenie geograficzne, rozbudowana przestrzennie infrastruktura przemysłowa: techniczna i transportowa, różnice społeczne oraz napięta sytuacja polityczna stwarzają w Rosji potencjalne ryzyko występowania częstych sytuacji kryzysowych, takich jak: klęski żywioczy.

" Doktor nauk prawnych, Kujawsko-Pomorska Szkoła Wyższa w Bydgosz- 
łowe, awarie techniczne i konflikty społeczne zagrażające zdrowiu i życiu ludzi, bezpieczeństwu publicznemu, środowisku naturalnemu i mieniu w znacznych rozmiarach.

W związku z wystąpieniem sytuacji kryzysowych rosyjskie prawo przewiduje dwa rozwiązania instytucjonalne. Zależnie od powagi zagrożenia może to być wprowadzenie stanu wyjątkowego lub reżimu nadzwyczajnych sytuacji. Celem tego artykułu jest ogólna charakterystyka regulacji prawno-instytucjonalnej stanu wyjątkowego i reżimu nadzwyczajnej sytuacji w Federacji Rosyjskiej z uwzględnieniem aspektów związanych z ochroną środowiska.

\section{Słowa kluczowe}

Federacja Rosyjska; klęski żywiołowe; awarie techniczne; konflikty społeczne; stan wyjątkowy; reżim sytuacji nadzwyczajnej.

\section{ABSTRACT}

Russia's geographical location, spatially developed industrial, technical and logistic infrastructure, as well as social stratification and a tense political situation all contribute to the potential risk of crises such as natural disasters, technical failures, and social conflicts, which pose a great danger to people's health and lives, public safety, natural environment and property.

There are two institutional solutions to critical situations available in the Russian law. Depending on the seriousness of the danger those can be: introducing the state of emergency or the regime of an extraordinary situation. The aim of this article is to broadly characterize the legal and institutional regulations of the state of emergency and the regime of an extraordinary situation in the Russian Federation, taking into account the aspects concerning natural environment protection.

\section{Keywords}

Russian Federation; natural disasters; technical failures; social conflicts; state of emergency; regime of an extraordinary situation. 


\section{UWAGI WSTĘPNE}

Terytorium Federacji Rosyjskiej rozpościera się od Europy wschodniej po krańce północnej Azji, zajmując 1/3 obszaru Eurazji i $1 \frac{1}{9}$ światowego lądu. Rosja graniczy z 14 państwami, a jej obszar obejmuje 9 stref czasowych. Ze względu na zajmowaną przestrzeń federacja jest krajem o bardzo zróżnicowanym krajobrazie, rzeźbie terenu i klimacie.

Ze swoimi 144 milionami mieszkańców jest ona szóstym państwem na świecie pod względem zaludnienia. Z uwagi na zróżnicowane warunki środowiskowe i cywilizacyjne ludność Rosji rozmieszczona jest skrajnie nierównomiernie. Dwie trzecie żyje w europejskiej części kraju, przy czym w samej Moskwie ponad 12 milionów, a zatem więcej niż na przykład w całej Belgii czy Grecji. Z drugiej strony zaludnienie azjatyckiej części kraju jest jednym z najmniejszych na świecie i wynosi średnio 1,9 mieszkańca na kilometr kwadratowy ${ }^{1}$.

Federacja Rosyjska to ziemia wielu kultur, narodowości i religii. Przetrwało tu ponad 194 narodów i mniejszości etnicznych ${ }^{2}$, działa kilkaset wspólnot religijnych, reprezentujących niemal wszystkie religie i wyznania współczesnego świata. W Rosji obowiązuje 37 języków państwowych, a dodatkowych 15 posiada oficjalny status, ogółem w użyciu pozostaje 164 żywych języków ${ }^{3}$.

Gospodarka Rosji zaliczana jest do czołówki światowej. W przemyśle zatrudnionych jest $32 \%$ społeczeństwa, co w znacznym stopniu rozwiązuje problem bezrobocia. Dominuje przemysł ciężki: surowcowo-energetyczny, metalurgiczny, mineralny, chemiczny oraz zbrojeniowy. Ośrodki przemysłowe Rosji

1 Ale na przykład w ewenkijskim rejonie Kraju Krasnojarskiego jest to 0,02, a na Czukotce - 0,07 mieszkańca na kilometr kwadratowy, https://ru.wikipedia.org/wiki/Население_России [dostęp: 12.03.2015 r.]

2 Список, численность и процентаж народов России http://www.opoccuu.com/narody.htm [dostęp: 12.03.2015 r.]

3 https://ru.wikipedia.org/wiki/ Языки_России [dostęp: 12.03.2015 r.] 
połączone są międzykontynentalnymi sieciami transportowymi i przesyłowymi.

Położenie geograficzne, rozbudowana przestrzennie infrastruktura przemysłowa, techniczna i transportowa, różnice społeczne oraz napięta sytuacja polityczna stwarzają potencjalne ryzyko występowania częstych sytuacji kryzysowych, takich jak: klęski żywiołowe, awarie techniczne, konflikty społeczne zagrażające zdrowiu i życiu ludzi, bezpieczeństwu publicznemu, środowisku naturalnemu i mieniu w znacznych rozmiarach.

W związku z wystąpieniem sytuacji kryzysowych rosyjskie prawo przewiduje dwa rozwiązania instytucjonalne. Zależnie od powagi zagrożenia może to być wprowadzenie stanu wyjątkowego lub reżimu nadzwyczajnych sytuacji.

Stan wyjątkowy (ros. czierezwyczajnoje położenie) to instrument konstytucyjny stosowany w przypadku wystąpienia najpoważniejszych kryzysów wewnętrznych oraz klęsk żywiołowych. Ostatnio miał zastosowanie w 2010 roku ze względu na ogromne pożary lasów, a wcześniej - w 1993 roku, w związku z przewrotem konstytucyjnym. Natomiast reżim sytuacji nadzwyczajnych (ros. czierezwyczajnaja sytuacja, w skrócie s.n.), jako „mały” stan wyjątkowy, uregulowany ustawą federalną, wprowadzany jest co najmniej kilkadziesiąt razy do roku. Celem tego artykułu jest ogólna charakterystyka regulacji prawno-instytucjonalnej stanu wyjątkowego i reżimu nadzwyczajnej sytuacji w Federacji Rosyjskiej z uwzględnieniem aspektów związanych z ochroną środowiska.

\section{STAN WYJĄTKOWY}

Stan wyjątkowy to szczególny tryb działania organów władzy publicznej, przedsiębiorstw, instytucji i organizacji wprowadzany na całym obszarze państwa lub na części jego terytorium dla ochrony przed zagrożeniem wewnętrznym lub 2/2015 zewnętrznym i utrzymania porządku społecznego. Reżim stanu 
wyjątkowego przewiduje ograniczenie praw i wolności obywateli, osób prawnych a także nałożenie na nich dodatkowych obowiązków ${ }^{4}$.

Po raz pierwszy w historii Rosji stan wyjątkowy został wprowadzony po zabójstwie cara Aleksandra II - dekretem z 1881 roku. Początkowo miał on obowiązywać tylko tymczasowo, jednakże co roku, aż do rewolucji lutowej, dekret odnawiano. Po rewolucji październikowej władza sowiecka wydała w 1923 roku dekret o nadzwyczajnych środkach ochrony rewolucyjnego porządku, zgodnie z którym stan wyjątkowy wprowadzany był na wniosek NKWD ${ }^{5}$.

Konstytucje sowieckie nie normowały stanu wyjątkowego, powierzając te kwestie prawodawstwu zwykłemu. Do przedmiotowego zagadnienia odniosła się dopiero Konstytucja Federacji Rosyjskiej z 1993 roku$^{6}$. W jej rozdziale II zatytułowanym Prawa i wolności człowieka i obywatela, artykuł 56 ust. 1 stanowi, że: „W warunkach stanu wyjątkowego w celu zapewnienia bezpieczeństwa obywateli i obrony ustroju konstytucyjnego zgodnie z federalną ustawą konstytucyjną w odniesieniu do poszczególnych praw i wolności mogą być wprowadzone ograniczenia ze wskazaniem ich zakresu i terminu obowiązywania". Kolejny ustęp tego artykułu stanowi, że „Stan wyjątkowy na całym terytorium Federacji Rosyjskiej i w jej poszczególnych częściach może być wprowadzany w wypadku zaistnienia okoliczności i w trybie przewidzianym federalną ustawą konstytucyjną". Ostatni ustęp tego artykułu enumeratywnie wymienia prawa i wolności, które nie podlegają ograniczeniu (m.in. prawo do życia, godność osobista, ochrona prywatności, wolność sumienia i wyznania, prawo do mieszkania, prawo do sądu) ${ }^{7}$.

4 Федеральный конституционный закон от 30.05.2001 N 3-ФКЗ О чрезвычайном положении, http://www.consultant.ru/document/cons_doc_ LAW_160083/ [dostęp: 12.03.2015 r.]

5 Декрет ВЦИК, СНК РСФСР от 08.03.1923 О чрезвычайных мерах охраны революционного порядка, http://naukaprava.ru/Home/ReadNews/1616.

6 Tekst Konstytucji FR w tłumaczeniu A. Kubika dostępny na http://libr. sejm.gov.pl/tek01/txt/konst/rosja.html.

7 Na temat ochrony środowiska w Konstytucji FR zob. B. Rakoczy, Problematyka ochrony środowiska $w$ konstytucji Federacji Rosyjskiej, „Prawo i Środo- 
Kolejny przepis konstytucyjny odnoszący się do stanu wyjątkowego znajdujemy $\mathrm{w}$ rozdziale IV poświęconym pozycji ustrojowej prezydenta. W świetle art. 88: „Prezydent Federacji Rosyjskiej w okolicznościach i w trybie przewidzianym federalną ustawą konstytucyjną wprowadza na terytorium Federacji Rosyjskiej lub w jej poszczególnych częściach stan wyjątkowy, niezwłocznie powiadamiając o tym Radę Federacji i Dumę Państwową". Warto zauważyć, że w tym samym rozdziale uregulowane zostało również wprowadzenie stanu wojennego analogicznie - dekretem prezydenta, przy czym, w tym wypadku, konstytucja wskazuje przesłanki jego wprowadzenia: „w wypadku agresji przeciwko Federacji Rosyjskiej lub bezpośredniej groźby agresji”.

Ponadto stan wyjątkowy upominany jest w Konstytucji RF jeszcze w kontekście zakazu rozwiązywania Dumy Państwowej. Niższa izba parlamentu nie może zostać rozwiązana w okresie obowiązywania stanu wojennego lub wyjątkowego wprowadzonego na całym terytorium państwa.

Przy analizie powyższych przepisów pirma facie zwraca uwagę fakt, że rosyjski ustrój konstytucyjny przewiduje tylko dwa stany nadzwyczajne, tj. wojenny i wyjątkowy. To odróżnia regulację rosyjską od polskiej, gdzie występuje jeszcze stan klęski żywiołowej jako odrębny rodzaj stanu nadzwyczajnego. W Polsce stan wyjątkowy może być wprowadzony rozporządzeniem Prezydenta wydanym na wniosek Rady Ministrów w razie zagrożenia konstytucyjnego ustroju państwa, bezpieczeństwa obywateli lub porządku publicznego. Natomiast stan klęski żywiołowej może być wprowadzony rozporządzeniem Rady Ministrów, „w celu zapobieżenia skutkom katastrof naturalnych lub awarii technicznych noszących znamiona klęski żywiołowej oraz w celu ich usunięcia”. Polska konstytucja wymienia

wisko" 2004, nr 3; M. Micińska-Bojarek, Prawnoustrojowe podstawy ochrony zasobów naturalnych Federacji Rosyjskiej, w: Fenomen Rosji. Pamięć przeszłości i perspektywy rozwoju. Kontekst polityczny i gospodarczy, red. J. Diec, A. Jach, Kraków 2014; zob. też: M. Micińska-Bojarek, Geopolityczno prawne uwarunkowania gospodarki zasobami naturalnymi Federacji Rosyjskiej, w: Prawne aspekty gospodarowania zasobami środowiska. Korzystanie z zasobów, red. B. Rakoczy, M. Szalewska, K. Karpus, Toruń 2014. 
też jakie prawa i wolności mogą zostać ograniczone. W Rosji w warunkach klęski żywiołowej wprowadza się stan wyjątkowy, a konstytucja wymienia prawa i wolności, które nie mogą zostać ograniczone.

Zwraca uwagę fakt, że - w odróżnieniu od polskich rozwiązań ustrojowych - Konstytucja FR gwarantuje pełną samodzielność Prezydenta FR przy podejmowaniu decyzji o wprowadzeniu danego stanu. Ponadto w Konstytucji FR nie ma odrębnego rozdziału poświęconego stanom nadzwyczajnym, gdyż kwestie te są, dość lakonicznie, unormowane przy kompetencjach prezydenta. Inaczej niż w Konstytucji RP, rosyjska ustawa zasadnicza nie określa ani przesłanek umożliwiających wprowadzenie stanu wyjątkowego, ani warunków jego przedłużenia i uchylenia.

Szczegółową regulację zagadnień związanych z wprowadzaniem, obowiązywaniem i uchyleniem stanu wyjątkowego znajdujemy natomiast $\mathrm{w}$ federalnej ustawie konstytucyjnej o stanie wyjątkowym. Regulacja ta została podpisana przez Prezydenta Władimira Putina 30 maja 2001 r. i weszła w życie z chwilą ogłoszenia ${ }^{8}$. Zastąpiła ona Ustawę z dnia 3 kwietnia maja 1990 r. o prawnym reżimie stanu wyjątkowego ${ }^{9}$. Regulacja z 2001 roku stanowi, iż stan wyjątkowy wprowadza się tylko przy wystąpieniu okoliczności stanowiących bezpośrednie zagrożenie życia i bezpieczeństwa obywateli i ustroju konstytucyjnego Federacji Rosyjskiej, a uniknięcie ich nie jest możliwe bez podejmowania nadzwyczajnych środków. Ustawa przewiduje dwa rodzaje takich okoliczności:

- próby zmiany ustroju konstytucyjnego przy użyciu siły, odebranie lub przyswojenie władzy, zbrojna rebelia, masowe zamieszki, akty terrorystyczne, blokowanie lub zajęcie szczególnie ważnych obiektów i miejsc, przygotowywanie i działalność nielegalnych formacji zbrojnych,

8 Федеральный конституционный закон от 30.05.2001 N 3-ФК3 О чрезвычайном положении, http://www.consultant.ru/document/cons_doc_ LAW_160083/ [dostęp: 12.03.2015 r.]

9 Закон СССР от 03.04.1990 N 1407-1 О правовом режиме чрезвычайного положения, http://lawrussia.ru/texts/legal_861/doc861a825x225.htm [dostęp: 12.03.2015 r.] 
konflikty narodowościowe i religijne, konflikty regionalne przebiegające $\mathrm{z}$ użyciem przemocy, powodujące bezpośrednie zagrożenie życia i bezpieczeństwa obywateli oraz normalnej działalności organów władzy państwowej i samorządu terytorialnego;

- nadzwyczajne sytuacje o naturalnym i technicznym charakterze, nadzwyczajne sytuacje ekologiczne (w tym epidemie i epizootie), występujące w rezultacie awarii czy niebezpiecznych zjawisk naturalnych, katastrof, klęsk żywiołowych i innych, powodujące (lub mogące spowodować) ofiary w ludziach, szkodę na zdrowiu ludzi i w środowisku naturalnym, znaczne straty materialne, zniszczenie warunków życia ludzi, wymagające przeprowadzenia szeroko zakrojonych prac awaryjno-ratunkowych.

Dalej ustawa z 2001 roku stanowi, że Prezydent FR może wprowadzić na całym terytorium państwa stan wyjątkowy na okres nie dłuższy niż 30 dni. Natomiast stan wyjątkowy na określonym obszarze - na okres nie dłuższy niż 60 dni. Przedłużenie trwania stanu może nastąpić tylko na mocy nowego dekretu Prezydenta FR.

Dekret prezydenta nie wymaga wyrażenia uprzedniej zgody przez władze podmiotów federacji, jednakowoż musi być on zatwierdzony przez Radę Federacji w możliwie krótkim czasie, nie dłuższym niż 72 godzin od jego ogłoszenia. Dekret niezatwierdzony przez Radę Federacji automatycznie traci moc po upływie trzech dni od momentu jego ogłoszenia. Jak wiadomo, Rada Federacji stanowi wyższą izbę parlamentu rosyjskiego, w skład której wchodzi po dwóch przedstawicieli z każdego podmiotu federacji (republik, krajów, obwodów, okręgów autonomicznych, obwodu autonomicznego i miast o znaczeniu federalnym: Moskwy, Petersburga, Sewastopola).

Jak już wspomniano, podczas trwania stanu wyjątkowego na całym terytorium kraju Rada Federacji i Duma Państwowa kontynuują swoją pracę i nie mogą zostać rozwiązane. Po wprowadzeniu stanu wyjątkowego na określonym obszarze FR wybory i referenda nie odbywają się do momentu zniesienia stanu wyjątkowego przy automatycznym przedłużeniu okresu pełno- 
mocnictw organów władzy państwowej i organów samorządu terytorialnego.

Dekret prezydencki powinien zawierać m.in.: wskazanie granic objętych stanem, odpowiedzialne organy, właściwe służby i straże, wykaz tymczasowych ograniczeń praw i wolności obywateli FR, osób prawnych, cudzoziemców, termin wejścia w życie i czas trwania stanu. Dekret podlega bezzwłocznemu ogłoszeniu w radiu i telewizji oraz oficjalnemu opublikowaniu.

Podczas stanu wyjątkowego mogą być wprowadzone: godzina policyjna, ograniczenia wolności prasy i druku, cenzura, zakaz działalności określonych partii politycznych i innych organizacji, kontrola dokumentów, bagażu, zakaz sprzedaży broni i amunicji, odebranie broni i amunicji obywatelom a także przedłużenie odbywania kary skazanym za określone przestępstwa (terroryzm). Ponadto dopuszcza się przesiedlenia, kwarantanny, nakazy i zakazy dotyczące działalności gospodarczej określonego typu, zajęcie środków transportu, pomieszczeń, mobilizacja zdolnych od pracy.

Obowiązywanie reżimu stanu wyjątkowego zabezpieczają przede wszystkim organy ministerstwa spraw wewnętrznych, do których zalicza się: policja, federalne służby bezpieczeństwa oraz wojska wewnętrzne MSW, w skład którego wchodzą: jednostki lądowe, morskie, lotnicze i specjalne (specnaz), ponadto organy wykonawcze wymiaru sprawiedliwości (służby więzienne i penitencjarne). W szczególnych sytuacjach prawo dopuszcza użycie Sił Zbrojnych Federacji Rosyjskiej oraz innych wojsk i formacji.

Dla sprawnego i jednolitego kierownictwa służbami i stażami Prezydent RF wyznacza komendanta terytorium objętego stanem wyjątkowym. Jego szerokie kompetencje określa ustawa. Ponadto, jeśli sytuacja tego wymaga, na obszarze objętym stanem wyjątkowym prezydent wyznacza specjalny, tymczasowy organ władzy państwowej. W takich sytuacjach ustawa wymaga, aby prezydent zwrócił się poprzez środki masowego przekazu z bezpośrednim apelem do społeczeństwa i uzasadnił w nim konieczność wprowadzenia szczególnego trybu sprawowania władzy na obszarze objętym stanem wyjątkowym. 
Jak już wspomniano, ten konstytucyjny instrument wykorzystywany jest w praktyce stosunkowo rzadko. Po rozpadzie ZSRR nie wprowadzano stanu wyjątkowego na ogólnofederalnym poziomie, jednakże dwa razy - na części terytorium Rosji. I tak w październiku 1993 roku Prezydent Borys Jelcyn wprowadził stan wyjątkowy w Moskwie celem rozwiązania kryzysu politycznego. Kryzys ten wywołany został rozwiązaniem Rady Najwyższej, która zdecydowanie sprzeciwiała się przyjętemu przez prezydenta kierunkowi reform gospodarczych. Parlament uznał swoje rozwiązanie za przewrót państwowy, ponieważ było ono niezgodne z ówczesną konstytucją. W Moskwie wybuchły zamieszki między zwolennikami obu stron. Po wprowadzeniu stanu wyjątkowego wobec przeciwników Jelcyna zastosowano wojsko, czołgi rozstrzelały budynek parlamentu, żołnierze i milicjanci spacyfikowali opozycję. W rezultacie walk zginęło 147 osób, w tym 124 cywili $^{10}$.

Drugi stan wyjątkowy miał przyczynę naturalną. Pod koniec lipca 2010 r. pożary wywołane wysokimi temperaturami i suszą trawiły już ponad 200 tysięcy ha lasów, a trujący smog docierał do Moskwy, w której liczba zgonów wzrosła dwukrotnie powyżej średniej. 2 sierpnia Prezydent Dimitrij Miedwiediew ogłosił stan wyjątkowy w 7 podmiotach federacji (2 republikach i 5 obwodach) ${ }^{11}$. Do walki z żywiołem skierowano Siły Zbrojne FR, a na pomoc ruszyli strażacy z wielu państw Europy, w tym z Polski. W ogniu zginęły 54 osoby, wiele zostało poszkodowanych, spłonęło ponad 2000 budynków.

10 Жертвы «чёрного октября» http://ruskline.ru/analitika/2013/09/28/ zhertvy_chyornogo_oktyabrya/.

11 Указ об объявлении чрезвычайной ситуации, связанной с обеспечением пожарной безопасности, в семи субъектах Российской Федерации, http:// kremlin.ru/news/8558 [dostęp: 12.03.2015 r.] 


\section{REŻIM SYTUACJI NADZWYCZAJNEJ}

Jak już wspomniano, reżim sytuacji nadzwyczajnej to „mały” stan wyjątkowy, nieumocowany na szczeblu konstytucyjnym. Kompleksową regulację reżimu s.n. zawiera Ustawa federalna z dnia 21 grudnia 1994 roku o ochronie społeczeństwa i terytorium przed sytuacjami nadzwyczajnymi naturalnego i technicznego charakteru ${ }^{12}$. Zgodnie $\mathrm{z}$ jej przepisami sytuacja nadzwyczajna to „sytuacja, która wystąpiła na określonym terytorium lądowym lub wodnym w rezultacie awarii, niebezpiecznego zjawiska przyrodniczego, katastrofy, klęski żywiołowej, które może pociągnąć za sobą (lub już pociągnęła) ofiary w ludziach, szkodę na zdrowiu i w środowisku naturalnym, znaczące straty materialne i naruszenie warunków działalności ludzkiej".

Celem ustawy z 1994 roku jest zapobieganie i przeciwdziałanie nadzwyczajnym sytuacjom, zminimalizowanie rozmiarów strat z nich wynikających oraz likwidacja ich skutków a ponadto rozgraniczenie przedmiotowych kompetencji między organami władzy: federalnymi, podmiotów federacji i samorządu terytorialnego. Ustawa tworzy podstawę prawną dla jednolitego państwowego systemu zapobiegania i likwidacji sytuacji nadzwyczajnych, przewidując w razie konieczności możliwość użycia nie tylko służb, straży i wojska ministerstwa spraw wewnętrznych, ale również Sił Zbrojnych FR.

Ponadto akt ten określa prawa i obowiązki obywateli federacji w związku z zaistnieniem sytuacji nadzwyczajnej, zapewniając jednocześnie jawność i dostęp do informacji w przedmiotowym zakresie. Obywatele maja prawo do: ochrony życia i zdrowia, do ochrony majątku osobistego, prawo do informacji o ryzyku i środkach bezpieczeństwa, do składania petycji. Ponadto mają prawo do: odszkodowania za uszczerbek na zdrowiu i mieniu, do obsługi medycznej, do świadczeń

12 Федеральный закон от 21.12.1994 N 68-Ф3 (ред. от 14.10.2014) О защите населения и территорий от чрезвычайных ситуаций природного и техногенного характера, http://www.consultant.ru/document/cons_doc_LAW_169811/. 
socjalnych i kompensacji za przebywanie na obszarze objętym s.n. (w zonie) ${ }^{13}$, za pracę podczas likwidacji skutków sytuacji nadzwyczajnych. W szczególności obywatele mają prawo do rent i emerytur w związku z kalectwem i utratą zdolności do pracy, a rodziny, które utraciły żywiciela - prawo do zabezpieczenia socjalnego. Natomiast do obowiązków obywateli należy przestrzeganie prawa, regulaminów i środków bezpieczeństwa pracy, dyscypliny technologicznej, wymogów bezpieczeństwa ekologicznego. Ponadto obowiązkiem obywateli jest ustawiczne szkolenie się w zakresie sposobów ochrony ludności i terytorium oraz w zakresie udzielania pierwszej pomocy medycznej, a w razie konieczności bezpośredni udział w pracach awaryjno-ratunkowych.

Kolejny rozdział ustawy zawiera przepisy dotyczące obowiązku rozpowszechniania wśród ludności wiedzy i umiejętności służącej zapobieganiu sytuacjom nadzwyczajnym. Na koniec ustawa stanowi o źródłach finansowania, przeprowadzaniu państwowych ekspertyz, o formach kontroli i nadzoru w przedmiotowym zakresie. Warto jeszcze raz podkreślić, że komentowany akt nie dopuszcza możliwości ograniczenia konstytucyjnych praw i wolności człowieka oraz obywatela.

Pewne wątpliwości może natomiast budzić fakt, że ustawa z 1994 roku nie zawiera określenia, czym jest sam reżim prawny s.n., jakimi cechami się charakteryzuje, jaka powinna być treść rozporządzenia organu władzy wykonawczej wprowadzającego reżim i w jakiej formie akt ten podawany jest do publicznej wiadomości. Kwestie te pozostawione zostały do uregulowania w ustawodawstwie poszczególnych podmiotów federacji. Zgodnie bowiem z art. 72 ust.1 lit.h Konstytucji FR zwalczanie katastrof, klęsk żywiołowych, epidemii oraz likwidowanie ich skutków leży we wspólnej kompetencji Federacji Rosyjskiej i jej podmiotów. Z przeprowadzonej przeze mnie analizy aktów wydanych w konkretnych sytuacjach nadzwy-

13 W rosyjskim prawie oprócz zon sytuacji nadzwyczajnej istnieją też zony klęski ekologicznej, więcej na ten temat zob. M. Micińska-Bojarek, Obszary klęski ekologicznej Federacji Rosyjskiej - status prawny i programy naprawcze, „Prawo i Środowisko” 2014, nr 4. 
czajnych wynika, że są to rozporządzenia porządkowe, które zawierają przepisy uruchamiające poziom kryzysowego reagowania służb i staży w celu zabezpieczenia warunków życia ludzi, ewakuacji i ratownictwa; ponadto określają jednostki terytorialne objęte reżimem i wyznaczają konkretną osobę (komendanta) odpowiedzialną za jego wykonywanie prac. Akty te podlegają opublikowaniu na stronach internetowych właściwych urzędów oraz rozpowszechnieniu w środkach masowego przekazu.

Klasyfikację sytuacji nadzwyczajnych - ze względu na kryteria obszaru objętego oddziaływaniem (wielkość zony s.n.), liczby ofiar (zabitych i rannych) oraz rozmiaru szkód środowiskowych i strat majątkowych - zawiera Rozporządzenie Rządu FR z dnia 21 maja 2007 w sprawie kwalifikacji nadzwyczajnych sytuacji o naturalnym i technicznym charakterze $^{14}$. Wyróżniamy zatem sytuacje nadzwyczajne o charakterze:

- lokalnym - w rezultacie której zona s.n. nie wykracza poza granice miejsca zdarzenia, liczba ofiar nie przekracza 10 osób, a rozmiar szkody w środowisku i strat materialnych nie przekracza 100 tys. rubli;

- municypalnym - w rezultacie której zona s.n. nie wykracza poza granice jednej osady (miejskiej lub wiejskiej) lub terytoriów wewnątrzmiejskich miast federalnego znaczenia (tj. okręgów municypalnych, okręgów miejskich) ${ }^{15}$, liczba ofiar nie przekracza 50 osób lub rozmiar szkód i strat nie przekracza $5 \mathrm{mln}$ rubli;

- międzymunicypalnym - w rezultacie której zona s.n. obejmuje terytorium dwóch lub więcej osad lub terytoriów wewnątrzmiejskich miast federalnego znaczenia lub terenów międzyosadniczych (tj. obszarów o bar-

14 Постановление Правительства Российской Федерации от 21. 05. 2007 $\mathrm{N} 304$ О классификации чрезвычайных ситуаций природного и техногенного характера, http://www.consultant.ru/document/cons_doc_LAW_114211/ [dostęp: 12.03.2015 r.]

15 Zob. szerzej. M. Micińska-Bojarek, Samorząd lokalny w Federacji Rosyjskiej, „Samorząd Terytorialny” 2015 (artykuł przyjęty do druku). 
dzo niskiej gęstości zaludnienia gdzie nie tworzy się jednostek samorządowych pierwszego szczebla ${ }^{16}$ ) przy czym liczba ofiar nie przekracza 50 osób lub rozmiar szkód i strat - $5 \mathrm{mln}$ rubli;

- regionalnym - w rezultacie której zona s.n. nie wychodzi poza obszar jednego z pomiotów federacji (republik, obwodów, okręgów, krajów i miast federalnego znaczenia), liczba ofiar mieści się w przedziale 50-500 osób lub rozmiar szkód i strat w przedziale 5-500 mln rubli;

- międzyregionalnym - w rezultacie której zona s.n. obejmuje terytorium dwóch lub więcej podmiotów federacji, liczba ofiar mieści się w przedziale 50-500 lub rozmiar szkód i strat w przedziale $5-500 \mathrm{mln}$ rubli;

- federalnym - w rezultacie której liczba ofiar przekracza 500 osób lub rozmiar szkód i strat przekracza 500 mln rubli.

Powyższa klasyfikacja, po zmianie Rozporządzenia z dnia 17 maja 2011 roku, nie dotyczy pożarów lasów, które mają kwalifikację odrębną określoną w tymże znowelizowanym rozporządzeniu ${ }^{17}$.

Z przepisów ustawy z 1994 roku, zawierających rozgraniczenie kompetencji władz federalnych, regionalnych (podmiotów federacji) i municypalnych, wynika, że - w zależności od charakteru sytuacji nadzwyczajnej - mamy różne organy właściwe do wydania aktu o wprowadzeniu reżimu s.n. $\mathrm{Na}$ poziomie federalnym i międzyregionalnym jest to Rząd FR. Na poziomie regionalnym i międzymunicypalnym (ponadlokalnym) wprowadzenie reżimu s.n. należy do kompetencji władzy wykonawczej poszczególnych podmiotów federacji. Przy czym w obwodach, krajach i okręgach jest to gubernator, w republikach - w zależności od przepisów konstytucji poszczególnych republik - może to być premier bądź prezydent,

16 Ibidem.

17 Постановление Правительства Российской Федерации от 17 мая 2011 г. N 376 О чрезвычайных ситуациях в лесах, возникших вследствие лесных пожаров, http://www.rg.ru/2011/05/25/fire-dok.html. 
natomiast $\mathrm{w}$ miastach federalnego znaczenia - mer. Na poziomie municypalnym i lokalnym niższego szczebla (w Rosji samorząd terytorialny jest dwustopniowy) reżim sytuacji nadzwyczajnej wprowadzany jest aktem prawa miejscowego wydanym przez organ wykonawczy danej jednostki samorządowej. Przykładowo w 2014 roku reżim s.n. poziomu regionalnego został wprowadzony Rozporządzeniem Prezydenta Republiki Jakucji z dnia 29 lipca w związku z podniesieniem się na skutek ulewnych deszczy poziomy wód w rzekach Dułagach, Lena, Moma, Jana, Indigirka ${ }^{18}$. Reżim poziomu międzymunicypalnego wprowadzony został 2 grudnia przez gubernatora Kraju Chabarowskiego z powodu śnieżnego cyklonu ${ }^{19}$. Natomiast reżim poziomu municypalnego został wprowadzony 25 grudnia przez władze miasta Tuapse w Kraju Krasnodarskim z powodu awarii naftociągu i zanieczyszczenia rzeki Tuapse oraz wybrzeży Morza Czarnego ${ }^{20}$.

W sprawach związanych z sytuacjami nadzwyczajnymi organy federalne, regionalne i municypalne współdziałają ze specjalistycznymi organami wspomnianego wyżej jednolitego państwowego systemu zapobiegania i likwidacji sytuacji nadzwyczajnych. Utworzony w drodze Rozporządzenia Rządu FR z dnia 30 grudnia 2003 roku $^{21}$ system łączy w jednym pionie organizacyjnym organy władzy publicznej oraz podporządkowane im służby i straże. W skład systemu wchodzą: kluczowe ministerstwa federalne, federalne inspekcje nadzoru administracyjnego, państwowe korporacje Rosatom i Roskosmos a ponadto szereg organów - komisji działających na poziomie

18 На территориях Верхоянского, Момского, Оймяконского улусов объявлен режим ЧС, http://www.sakha.gov.ru/node/122557 [dostęp: 12.03.2015 r.]

19 Режим чрезвычайной ситуации введен в Хабаровске, http://www. gubernia.com/news/society/rezhim-chrezvychaynoy-situatsii-vveden-vkhabarovske/?sphrase_id=179940 [dostęp: 12.03.2015 r.]

20 Последствия утечки нефти в Туапсе ликвидированы на 90\%, http:// www.krasnodar.ru/content/2/show/208902/ [dostęp: 12.03.2015]

21 Постановление Правительства РФ от 30.12.2003 N 794 (ред. от 15.02.2014) О единой государственной системе предупреждения и ликвидации чрезвычайных ситуаций, http://www.consultant.ru/document/cons_doc_ LAW_159106/ [dostęp: 12.03.2015 r.] 
międzyregionalnym, regionalnym i municypalnym. Ogniwem koordynującym system jest ministerstwo sytuacji nadzwyczajnych (MSN) mające swoje oddziały terenowe na poziomie międzyregionalnym, to jest w dziewięciu okręgach federalnych $^{22}$, oraz regionalnym.

Samo ministerstwo powstało w 1994 roku, a jego pierwszym szefem był Siergiej Szojgu, który pełnił obowiązki w MSN do 2012 roku, kiedy to został powołany na stanowisko ministra obrony narodowej. Do monitoringu sytuacji nadzwyczajnych i do likwidacji ich skutków ministerstwo dysponuje kilkunastoma rodzajami specjalistycznych służb i straży. Ponadto MSN prowadzi statystyki wydarzeń, które udostępniane są na jego oficjalnej stronie internetowej ${ }^{23}$. Wynika $\mathrm{z}$ nich między innymi, że tylko w przeciągu 3 ostatnich kwartałów 2014 roku miały miejsce: 2 awarie głównych gazociągów i naftociągów, 32 katastrofy lotnicze, 2 poważne awarie sieci energetycznych, 6 zawaleń budynków, 18 awarii w metrze, 2 epidemie, 16 epizootii, 16 silnych opadów, 10 zamieci, 1 osuwisko ziemi i 1 akt terrorystyczny.

Ogólnie rok 2014 był dla Rosji wyjątkowo trudnym, w całym kraju reżim s.n. wprowadzany był ponad 200 razy, przy czym największym wyzwaniem były nie katastrofy naturalne i awarie techniczne, ale kwestie społeczne, a mianowicie konieczność udzielenia schronienia i pomocy uciekinierom z objętej konfliktem Ukrainy. Według danych ONZ na marzec 2015 roku w Rosji zarejestrowało się około miliona uchodź-

22 Okręgi federalne to jednostki podziału terytorialnego FR niebędące podmiotami federacji, wprowadzone Dekretem Prezydenta FR Władimira Putina z dnia 13 maja 2000 roku - o pełnomocnym przedstawicielu Prezydenta Federacji Rosyjskiej w okręgu federalnym (Указ Президента Российской Федерации от 13 мая 2000 N 849 - О полномочном представителе Президента Российской Федерации в федеральном округе). Wyróżniamy: Centralny Okręg Federalny, Krymski Okręg Federalny, Południowy Okręg Federalny, Północno-Zachodni Okręg Federalny, Dalekowschodni Okręg Federalny, Syberyjski Okręg Federalny, Uralski Okręg Federalny, Nadwołżański Okręg Federalny, Północnokaukaski Okręg Federalny.

${ }^{23}$ http://www.mchs.gov.ru/operationalpage/digest/2014/. 
ców $^{24}$. W związku z ich napływem reżim s.n. poziomu regionalnego został wprowadzony w siedmiu podmiotach federacji, obwodach: rostowskim, wołgogradzkim i astrachańskim, krajach stawropolskim, i chabarowskim ${ }^{25}$, Republice Kałmucji oraz w mieście federalnego znaczenia - Sewastopolu ${ }^{26}$. Ministerstwo sytuacji nadzwyczajnych organizuje obozy przejściowe, udziela pomocy medycznej, socjalnej i psychologicznej, dzienny koszt utrzymania 1 uchodźcy szacuje się na około 800 rubli $^{27}$. Do marca 2015 roku MSN odprawiło na tereny objęte konfliktem czternaście konwojów ciężarówek z pomocą humanitarną.

\section{PODSUMOWANIE}

Podsumowując wyżej poczynione ustalenia, stwierdzić należy, że w ustroju konstytucyjnym Federacji Rosyjskiej wyróżniamy dwa rodzaje stanów nadzwyczajnych: stan wojenny i stan wyjątkowy. Ten ostatni może być wprowadzony nie tylko w przypadku zagrażających ustrojowi konstytucyjnemu konfliktów wewnętrznych, ale także w związku z wystąpieniem poważnej klęski żywiołowej lub awarii technicznej.

Jednakże uwarunkowania infrastrukturalne, przestrzenne, geograficzne, klimatyczne oraz społeczno-polityczne powodują, że sytuacje kryzysowe, wymagające wprowadzenia szczególnego trybu działania organów władzy publicznej, przedsiębiorstw, instytucji i organizacji na poziomie lokalnym,

24 ONZ przedstawia bilans wojny na Ukrainie http://www.rp.pl/ artykul/1137772,1183051-ONZ-przedstawia-bilans-wojny-na-Ukrainie.html [dostęp: 12.03.2015 r.]

25 В Хабаровском крае введен режим ЧС из-за наплыва беженцев с Украины http://lenta.ru/news/2014/09/15/refugees.

26 Режим ЧС введен в 6 регионах РФ из-за ситуации с украинскими беженцами РИА Новости http://ria.ru/society/20140710/1015381190.htm1\#ixzz3TQ1sNNME.

27 На содержание каждого беженца с Украины выделили по 800 рублей в сутки http://ngs24.ru/news/1881471/view/ [dostęp: 12.03.2015 r.] 
ponadlokalnym i regionalnym występują w Rosji niemal na porządku dziennym, a w związku z tym wprowadzanie konstytucyjnego stanu wyjątkowego byłoby znacznym utrudnieniem dla normalnego funkcjonowania całego kraju, tworzyłoby też zbędne obciążenia organizacyjne i finansowe dla władz federalnych. W takich właśnie wypadkach ma zastosowanie reżim sytuacji nadzwyczajnych.

Władze regionalne i municypalne wsparte o jednolity system zarządzania kryzysowego przezwyciężają problemy związane $\mathrm{z}$ przewidywaniem, monitoringiem i likwidacją skutków sytuacji nadzwyczajnych. Ustrój konstytucyjny pozostawia im możliwość tworzenia własnych ustaw oraz aktów prawa miejscowego $\mathrm{w}$ przedmiotowym zakresie. W przeciwieństwie jednak do stanu wyjątkowego, reżim s.n. nie może ograniczać obowiązywania konstytucyjnych praw i wolności człowieka oraz obywatela.

Dwadzieścia lat temu powołane zostało Ministerstwo Spraw Nadzwyczajnych Rosji, które jest ministerstwem o priorytetowym znaczeniu w rządzie federalnym. Od 2003 r. jest ono odpowiedzialne za koordynację jednolitego systemu zarządzania kryzysowego na poziomie federalnym, międzyregionalnym i regionalnym. Ze względu na aktualną, szczególnie napiętą sytuację w rosyjskiej polityce zagranicznej i wewnętrznej należy spodziewać się, że następne lata przyniosą wiele nowych, trudnych wyzwań i sprawdzianów skuteczności tego systemu.

\section{BIBLIOGRAFIA}

Micińska-Bojarek M., Geopolityczno-prawne uwarunkowania gospodarki zasobami naturalnymi Federacji Rosyjskiej, w: Prawne aspekty gospodarowania zasobami środowiska. Korzystanie z zasobów środowiska, red. B. Rakoczy, M. Szalewska, K. Karpus, Torun 2014. Micińska-Bojarek M., Obszary klęski ekologicznej Federacji Rosyjskiej status prawny i programy naprawcze, „Prawo i Środowisko” 2014, nr 4. 
Micińska-Bojarek M., Prawnoustrojowe podstawy ochrony zasobów naturalnych Federacji Rosyjskiej, w: Fenomen Rosji. Pamięć przeszłości i perspektywy rozwoju. Kontekst polityczny i gospodarczy, red. J. Diec, A. Jach, Kraków 2014.

Micińska-Bojarek M., Samorząd lokalny w Federacji Rosyjskiej, „Samorząd Terytorialny" 2015 (artykuł przyjęty do druku).

Rakoczy B., Problematyka ochrony środowiska $w$ konstytucji Federacji Rosyjskiej, „Prawo i Środowisko” 2004, nr 3.

\section{Kontakt e-mail:}

m.micinska@kpsw.edu.pl 